\title{
Sintomas do modo de vida burguês no Vale do Paraíba, Séc.XIX: Fazenda São Fernando, Vassouras, RJ Exploração arqueológica e museológica
}

\author{
Tania Andrade Lima \\ Universidade Estácio de Sá \\ Pesquisadora/CNPq
}

Maria Cristina O. Bruno

MAE/Universidade de São Paulo

Marta P. R. da Fonseca

Pós-Graduada Universidade de São Paulo

Introdução

Objetivando resgatar arqueologicamente as evidências diretas das práticas cotidianas, rotineiras e anônimas da sociedade do Rio de Janeiro no século XIX, vêm sendo realizadas intervenções sistemáticas em unidades domésticas de áreas urbanas, em unidades de produção e habitação em áreas rurais e em espaços funerários desse período, com vistas à obtenção de novos elementos para o entendimento do processo de instalação do modo de vida burguês, que antecede a implantação da ordem burguesa propriamente dita no país, uma das peculiaridades da nossa formação social.

Considerando que nas primeiras décadas do século XIX esboçaramse as condições que permitiriam, em meados do século, a eclosão do chamado ciclo do café, vem sendo pesquisada a ocupação do Vale do Paraíba à luz desse processo econômico. Um programa de prospecções e escavações intensivas está sendo conduzido em fazendas da região, unidades produtivas de caté à época, investigando contextos da classe dominante, nas sedes, e da subalterna, nas senzalas. 
Antecedentes históricos

Ao se iniciar o século XIX, a colônia, que há três séculos desempenhava o papel de fornecedora de produtos minerais e agrícolas indisponiveis no mercado europeu, continuava com uma economia essencialmente agrária, baseada na monocultura, uma estrutura produtiva orientada para o mercado externo e dele dependente, sem qualquer autonomia e submetida às práticas monopolistas da metrópole.

Com a decadência da economia açucareira no nordeste, o eixo econômico, que já se deslocara no século XVlll do nordeste para a região das minas, transferiu-se ainda mais para o sul, no limiar do século XIX, com o esgotamento da produção do ouro, sobretudo a partir da instalação da sede da monarquia portuguesa no Rio de Janeiro.

Com o sistema colonial em processo de deterioração, o país encontrava-se, à essa altura, em franca decadência, em meio à ambivalente política econômica joanina. A única possibilidade da colônia reverter a conjuntura desfavorável em que se encontrava, seria através da sua reintegração ao comércio internacional, e essa oportunidade veio com a desorganização da produção do café no Haiti, em decorrência das guerras de independência ao final do século XVIII, o que ocasionou a elevação dos seus preços no mercado internacional. Esta alta estimulou a incremento à sua produção e graças à condições climáticas e topográficas favoráveis, a cultura foi extraordinariamente bem sucedida, de início no Rio de Janeiro e em seguida em Minas Gerais, São Paulo e Espírito Santo.

surto do café e a estrutura da sua produção

As primeiras mudas de café chegaram ao Brasil ainda no início do século XVIII, mais exatamente ao Pará. Difundiram-se rapidamente e até os primórdios do século XIX eram cultivadas em toda parte, porém apenas para consumo interno, em hortas, quintais e pomares.

No Rio de Janeiro o café espraiou-se de início pelo litoral, nas baixadas e encostas das montanhas. A observação e a experimentação, contudo, demonstraram que eram desaconselháveis para o seu cultivo as temperaturas elevadas e as áreas próximas a manguezais, sendo consideradas ideais as encostas bem drenadas, entre 300 e $1.200 \mathrm{~m}$ de altitude, temperaturas médias, chuvas regulares e solos férteis.

Em suas idas e vindas pelos caminhos que cruzavam a Serra do Mar, ligando o litoral ao interior, os tropeiros transportaram as primeiras mudas desse café que se alastrava ao longo da costa. Desta forma ele subiu a Serra do Mar, irradiando-se pelas terras mais altas do curso médio do Paraíba, em direção a Minas Gerais, e pelas encostas meridionais da Mantiqueira, que reuniam condições ideais para a expansão da nova cultura. 
Esse sertão, que até então permanecera em grande parte virgem, recoberto pela densa vegetação tropical da Mata Atlântica e ocupado por grupos indígenas Puri-Coroado; começara a ser cortado, no século XVIII, por caminhos abertos pelos tropeiros em direção às zonas de produção do ouro. $O$ trepidante movimento das tropas de mulas por essas estradas trouxe inúmeros posseiros à região, atraídos pelas possibilidades de comercialização de gêneros de primeira necessidade para os viajantes. Ranchos, estalagens e vendas floreceram em toda a sua extensão e nesse povoamento inicial em que a região do vale do Paraíba funcionou apenas como passagem entre um centro produtor e outro distribuidor, pouco interesse houve por uma fixação efetiva. As primeiras propriedades foram basicamente essas roças, estabelecidas em posses e em sesmarias.

A desagregação da economia mineira deslocou para a área do Vale antigos mineradores que se transformaram em agricultores ou criadores de gado, assim como antigos tropeiros, enriquecidos com o serviço de transporte e comércio de cargas. O capital acumulado nessas atividades econômicas, somado ao de comerciantes oriundos do próspero comércio do Rio de Janeiro e de portugueses transferidos com a corte, foi rapidamente canalizado para a nova empresa.

A virada do século XIX assistiu à intensificação da procura por terras nessa região, graças às novas possibilidades apresentadas pela expansão do café. Dentre os antigos posseiros, alguns obtiveram sesmarias, outros legitimaram suas posses. Muitas das roças de mantimentos transformaram-se em sítios e de novas ou antigas sesmarias surgiram as primeiras fazendas de café, simples e rústicas, com sedes toscas, de pau a pique e telhados de sapê, centradas nas mãos de umas poucas famílias.

Na segunda década do século XIX, a alta cotação do produto no mercado internacional incrementou fortemente a produção do café, que se tornou para o país uma nova fonte de divisas, possibilitando a sua revigoração econômica. Esse surto absolutamente espetacular pemitiu o enriquecimento súbito desses homens, abrindo-thes a possibilidade de uma rápida ascensão. Ameathando imensas fortunas, refinaram-se, sofisticaram seus modos de viver, poliram suas maneiras, subindo na hierarquia social. As moradias rústicas transformaram-se em amplas e abastadas sedes. Seus proprietários perderam o ar provinciano e ganharam ares fidalgais, com um verniz francamente europeu. As mesas cobriram-se de talheres, cristais e porcelanas. Remédios, produtos de toucador e objetos de uso sanitário revelavam o recém-adquirido cuidado com a saúde, aparência e higiene. Aos grandes proprietários e grandes produtores, o império concedeu títulos de nobreza, porém sem caráter hereditário. O poder acumulado garantiu a esses barões do café uma ativa participação na vida política da corte, onde importantes decisões eram tomadas e leis eram votadas, sempre de acordo com os seus interesses.

Riqueza e prestígio eram decorrência da quantidade de terras e escravos que possuíam. A vinculação do poder com a terra era, em muitos casos, claramente expressada nos brasões onde as iniciais do senhør eram substituídas pelas iniciais do nome da fazenda. Uma prática bastante comum, 
com raízes na religiosidade portuguesa, era a de designar as fazendas com o nome do santo homônimo do dono, numa curiosa simbiose em que o homem e sua terra recebiam a mesma denominação.

Por volta de 1850, as grandes propriedades já estavam formadas, concentradas nas mãos de umas poucas famílias. Através de uma forte associação entre elas nasceram poderosos clãs, que dominaram o cenário político, econômico e social, como os Werneck, Ribeiro de Avelar, Correia e Castro, Pais Leme, Breves, Teixeira Leite, entre outros.

O controle sobre essas terras era mantido através de casamentos, alianças, sociedades e consórcios, dentro da própria familia ou entre os clãs. Os dotes de casamento eram em geral terras e/ou escravos, divididos entre os herdeiros em caso de morte. Um eteito multiplicador era assegurado pela polífica de alianças, intra e interclânica, praticada pela classe dominante, que evitava assim a fragmentação da propriedade e garantia a sua supremacia.

Uma vez implantadas, as fazendas funcionavam como unidades de produção autônomas. Além da terra, cultivada pelos escravos, essas unidades eram formadas por uma sede, que abrigava o senhor e sua família, aí incluída a capela; pelas senzalas, casa do administrador, engenho para o beneficiamento do café, tulha e paiol para o armazenamento dos produtos, enfermaria, outras construções menores como estrebarias, chiqueiros, etc., e pelo terreiro, onde se lavava e secava o café.

A implantação dessas construções no relevo era determinada por fatores que deveriam atender à necessidades básicas, como a presença de água, abundante e límpida, para diversas finalidades: mover o maquinário do engenho, lavar o café, para o consumo diário na casa grande, para o gado. Por outro lado, a necessidade de controle sobre a escravaria e a produção determinava que da casa grande o senhor pudesse ter uma ampla visão do movimento diário da sua fazenda, o que recomendava a sua instalação num plano mais elevado que as demais edificações.

A disposição dessas construções compunha, em grande parte das fazendas, o chamado "quadrilátero funcional", no qual as construçōes se distribuíam ao redor do terreiro de café (prancha 1). Esta distribuição espacial era resultante de um rígido sistema de controle e fiscalização, onde todo o processo produtivo devia ficar sob as vistas do senhor.

A estrutura escravista de produção do café, baseada em um forte esquema de vigilância e disciplina, não eram convenientes grandes extensões territoriais. A divisão da terra em propriedades médias, de 100 a 200 alqueires, descentralizadas, que funcionassem como unidades completas e autônomas, cada qual com seu próprio cafezal, lavoura, sede, senzala, terreiro e tulha, permitia uma fiscalização mais efetiva. A centralização de várias dessas unidades em um único conjunto dificultaria a vigilância sobre a produção e a escravaria, pondo em risco seu bom funcionamento administrativo e rentabilidade. Assim sendo, em certos casos, um único senhor chegava a acumular diversas fazendas, confiando sua gestão a parentes ou administradores. Esse mecanismo possibilitava uma maior maleabilidade na obtenção de créditos, pois cada unidade garantia uma hipoteca, permitindo a um mesmo proprietário levantar diferentes financiamentos. 
Apesar de terem alcançado certa autonomia, com todo o processo produtivo sob controle, essas unidades permaneciam estruturalmente dependentes, tendo em vista que na etapa de comercialização estavam sujeitas ao ensacador, ao comissário, ao exportador. Assim sendo, embora inscritas em um modo de produção escravista colonial, articulavam-se plenamente com as práti-, cas em desenvolvimento do capitalismo liberal.

A falência da empresa cafeicultora no Rio de Janeiro

Esse movimento de expansão do café no Vale, totalmente alicerçado no braço escravo, que alcançou seu apogeu em meados do século XIX, foi refreado pelos entraves cada vez mais fortes à escravidão. A Inglaterra, precisando aumentar o mercado para seus produtos industrializados, lutava para implantar no país uma nova ordem, que permitisse não apenas a transferência do capital investido no comércio de escravos para outros setores, mas sobretudo a emergência de uma classe trabalhadora assalariada, potencialmente consumidora de seus bens industrializados. Mais ainda, a produção agrícola das colônias nas Antilhas, à base do trabalho livre, ficava em desvantagem em relação à produção brasileira que, desenvolvida com mão de obra escrava, entrava no mercadó internacional com preços mais competitivos. Era preciso desmantelar o sistema escravista a qualquer custo. Assim sendo, os ingleses começaram a apertar progressivamente o cerco, com o aumento das restrições ao tráfico, numa tentativa de estrangular o sistema escravista até a sua exaustão.

Por outro lado, a progressiva escassez de escravos nas lavouras, resultante dessas restrições, determinaram uma elevação sem precedentes nos seus preços, levando a uma violenta especulação por parte dos traficantes. Dependentes do trabalho do negro, os fazendeiros foram se endividando progressivamente. Contraíam empréstimos para a sua compra, dando suas propriedades como garantia. Sem condições de cumprir os compromissos assumidos, os senhores eram obrigados a entregar suas fazendas ou submeterem-se à execuções, no caso de dívidas bancárias.

O fim do tráfico deixou em disponibilidade o capital antes investido nos escravos, que passou a ser canalizado para outros setores, sobretudo o comércio e a indústria. Uma florescente burguesia urbana, progressivamente ganhando força e influência, passou a reivindicar também o fim da escravidão. Considerado como um entrave ao desenvolvimento, no momento crucial de transição para as relações de produção capitalistas, o regime tinha que ser extinto, de modo a permitir a transferência do poder da classe senhorial escravista para essa burguesia capitalista, uma maior disponiblidade de mão-de-obra para $\circ$ trabalho assalariado e o aumento do consumo no mercado interno.

O processo de deterioração e declínio do sistema foi se acelerando rapidamente, com as fugas e as revoltas de escravos se multiplicando. Paralelamente aumentava o número de emancipações, numa tentativa de aliviar a pressão, já insu- 
portável. A própria classe senhorial dava sinais de esgotamento, caminhando a passos largos para a ruptura, que agora atendia aos seus interesses.

A década de 80 caracterizou-se por uma profunda desorganização interna: dívidas contraídas, que davam escravos como garantia, não puderam ser resgatadas. Uma boa parte da colheita se perdeu por falta de braços: houve um maciço êxodo para as cidades, em meio a um clima de generalizado malestar, que em muito viria a contribuir para a queda do regime monárquico.

Entretanto, não foi a ausência do braço escravo o único fator determinante da ruína econômica do Vale. As práticas de cultivo, rigorosamente devastadoras, exauriram em poucos anos os solos férteis da região, e já por volta de 1870 a decadência era evidente. Abatidas as reservas florestais, devastadas as encostas, esgotados os solos, restaram colinas desnudas, totalmente estéreis. Uma vez removida a cobertura vegetal e plantado o café, foram criadas as condições ideais para a erosão dos morros. As chuvas torrenciais carrearam os solos húmicos pelas encostas abaixo, arrastando os estratos férteis e deixando para trás uma terra arrasada, tomada pelo mato e pela capoeira.

A ruína das matas e dos cafeicultores, o esgotamento da terra, o envelhecimento progressivo dos cafezais e a impossiblidade da sua reposição, aliados à flutuação do preço do café no mercado internacional, determinaram a falência da empresa cafeicultora no Vale. A exigência de novos espaços para a expansão do seu cultivo foi deslocando a lavoura no rumo do oeste paulista, ao encontro das terras roxas, onde, sob novas condições, à base do trabalho imigrante, o café viveria um novo surto.

\section{A Fazenda São Fernando e a sua inserção no universo cafeeiro}

A fazenda São Fernando, situada no distrito de Massambará, municipio de Vassouras, enquanto uma unidade de produção escravista no século XIX, acompanhou passo a passo, ao longo de toda a sua trajetória, o movimento de expansão, apogeu e decadência da cafeicultura no Vale do Paraíba fluminense, podendo ser considerada como um dos notáveis exemplos desse processo.

Rastreando a documentação cartorária disponivel,aí compreendidos inventários, testamentos, demarcações, execuções de sentenças, executivos hipolecários, livros de casamentos e óbitos de pessoas livres, em meticuloso trabalho feito pela Profa. Sonia Violeta de Andrade Motta, da Faculdade de Filosofia, Ciências e Letras de Vassouras e colaboradora desta pesquisa, foi possivel reconstituir toda a trajetória da São Fernando, até então desconhecida.

Originariamente uma posse de imigrantes portugueses e de mineiros deslocados das zonas auríferas, na primeira metade do século XVIII, foi requisitada enquanto uma sesmaria ao final do século, e nesse patrimônio fundiário foi desenvolvida a célula econômica que daria origem à São Fernando. A exploração inicial da propriedade foi feita por volta de 1815, por Fernándo Luís dos Santos Werneck, de forma simples, apenas para consumo interno. A esse 
tempo, a casa de vivenda era ainda coberta de palha, com parco mobiliário, simplicidade essa que foi uma característica da trajetória inicial dessas unidades produtoras. Por volta de 1850 a fazenda estava plenamente formada, com Fernando Luís e uma vasta prole vivendo com conforto e abastança.

Se ao longo da década de 50 ela conheceu o apogeu, no início dos anos 60 , sob a administração de um outro proprietário começou a sentir os sintomas do declínio do café, enfrentando os primeiros problemas decorrentes da crise da cafeicultura. Para superá-los, foram contraidos sucessivos empréstimos junto ao Banco do Brasil, mediante a hipoteca da propriedade. Os anos 70 e 80 foram marcados não apenas pelas dificuldades econômicas, mas também por atos de vandalismo e violência praticados contra a escravaria. Em 1882 morreu na São Fernando um escravo torturado pelo feitor e, refletindo bem a relação insustentável entre os senhores e seus escravos, há notícias de que em 1877 havia um quilombo nos domínios da fazenda, descrito como um rancho com cerca de 1 dúzia de negros que sobreviviam com produtos roubados de vendas e propriedades nas cercanias.

Em 1887, sem conseguir saldar as dívidas junto ao Banco do Brasil, a São Fernando foi executada. Seus bens foram seqüestrados e arrematados em praça pública, em 1889, e em seu arrolamento e descrição são utilizados termos como "arruinados", "estragados", "cobertos de capim", caracterizando bem a derrocada da unidade produtiva.

Este golpe final na Fazenda São Fernando foi dado, de forma bastante significativa, em 1889, no momento em que o país se abria para uma nova ordem política e econômica, após a ruptura do modo de produção escravista. As novas regras ditadas pelo capitalismo nascente não se aplicavam mais ao Vale exaurido, e os outrora poderosos senhores de terras, arruinados e desprestigiados, saíram de cena juntamente com o Império, deslocados pelas forças republicanas emergentes, comprometidas com a industrialização do país. Na virada do século, esgotado o ciclo que a produziu, a Fazenda São Fernando hibernava, preparando-se para a nova etapa que the reservava o século XX: a pecuária.

A imprevisibilidade no trato com o meio ambiente, a obtenção do máximo com um investimento mínimo e a ânsia por lucros rápidos derrubaram um sistema que, bem estruturado, poderia ter se mantido por tempo indeterminado, em níveis bastante satisfatórios. O ideário imediatista dessa burguesia nascente, porém, decretou sua própria sentença de morte, varrendo definitivamente deste cenário os barões do café

A recuperação material de um passado: a pesquisa arqueológica

Com o objetivo de recuperar evidências materiais das atividades cotidianas da Fazenda São Fernando, ao longo do século XIX, foram realizadas escavações arqueológicas em diversos pontos da propriedade. A pesquisa voltou-se primordialmente para as possíveis áreas de despejo de lixo, con- 
siderando-se o elevado potencial informativo desse tipo de material, capaz de refletir com grande fidelidade o comportamento do agente acumulador.

modo de vida implantado nesta unidade produtiva resultou, sobretudo, da interação de dois segmentos sociais fortemente polarizados: o subalterno, representado pela escravaria, e o dominante, constituído pelo senhor e sua família. Os homens livres que transitaram por esse universo, embora integrassem uma categoria ainda em gestação que, sob uma perspectiva mais abrangente, viria a ter uma signifiçaliva importância na formação social brasileira, foram de pouca expressão no âmbito limitado da célula econômica.

Com base nessa peculiaridade, a pesquisa arqueológica foi direcionada para a investigação da cultura material produzida e/ou utilizada por esses dois segmentos. No caso dos escravos, considerando a sua impossibilidade de registrar a própria história, a arqueologia procurou resgatar elementos materiais do seu dia-a-dia, para através deles tentar recuperar as práticas sócioculturais que os negros desenvolveram sob o jugo e a opressão. Coisas escondidas, esquecidas, enterradas, abandonadas, perdidas, altamente reveladoras da estrutura de um grupo, poderiam ser recobradas mediante escavações, trazendo novos elementos para o entendimento das estratégias de sobrevivência adotadas por essa etnia, no processo da sua instalação no Brasil.

Para tanto, foi selecionado prioritariamente para o início dos trabathos o local de habitação da escravaria: a senzala. Inteiramente arruinada, mas com a estrutura em pedra dos seus alicerces perfeitamente preservada, essa área foi considerada como passível de apresentar um elevado potencial de retorno.

A sua construção atendeu, à época, a um padrão adotado em toda a região: uma edificação alongada, avarandada e compartimentada, dividida em cômodos retangulares, os lances. Na São Fernando esses cômodos não seguem dimensões padronizadas e variam consideravelmente de tamanho, talvez em função dos grupos a que eram destinados: solteiros, casados, com prole, etc.; não obstante, pode-se dizer que apresentam em média $3.70 \mathrm{~m}$ de largura por $6.30 \mathrm{~m}$ de comprimento. Uma varanda com $1,50 \mathrm{~m}$ de largura acompanha o prédio em toda sua extensão, disposto em uma linha reta que é quebrada apenas na extremidade distal, de maneira a adequá-lo à topografia do terreno.

Dos 15 lances ainda remanescentes foram selecionados três para serem sistematicamente escavados. Numerados da direita para a esquerda, de 1 a 15, foram escolhidos aleatoriamente os de número 4, 9 e 14. Cada um desses cômodos foi dividido em setores, escavados de acordo com a deposição natural dos sedimentos e do material cultural aí contido.

Os três lances apresentaram idêntico comportamento estratigráfico: em seguida à remoção da camada húmica, com aproximadamente $10 \mathrm{~cm}$ de espessura, foi exposto um estrato de sedimento argilo-arenoso, amarelado, com presença de restos de argamassa do sistema construtivo de pau-a-pique. Subjacente a ela foi recuperado um nível de telhas fragmentadas, com uma densidade aproximada de 300 cacos por $\mathrm{m}^{2}$, sobreposto a um piso de terra batida, com um sedimento homogêneo, argiloso, de tonalidade avermelhada. 
Abaixo deste piso, foi exposto um sedimento arenoso e mosqueado, amarelo/acinzentado, sem qualquer vestígio arqueológico.

A éscavação efetuada recuperou basicamente elementos construtivos, como a argamassa do pau-a-pique, fragmentos de telhas, pregos e cravos. Pouquíssimos materiais foram resgatados: em torno de uma dezena de cacos de faiança branca, dois policromados e dúzia e meia de cacos de vidro, notadamente no cômodo 14.

A disposição estratigráfica desse material sugere que acima do piso da senzala e após a sua desativação, houve um desabamento do telhado, resultando na camada de telhas presente em todos os cômodos trabalhados. Em seguida desabaram as paredes de pau-a-pique, que foram recobertas, em tempos recentes, por terra preta destinada ao ajardinamento dos lances, reduzidos hoje em dia aos alicerces de pedra e transformados em canteiros de flores.

Outras intervenções foram feitas nas imediações da senzala, com resultados igualmente negativos. A frustante ausência de vestígios nos cortes executados pode ser interpretada de duas, maneiras: ou o sistema de controle sobre a escravaria na Fazenda São Fernando era de tal forma rígido, que aos negros era vedado qualquer tipo de tratha pessoal ou doméstica, ou, com a abolição, foram eliminados todos os testemunhos da escravidão, o que explicaria a evidência negativa. A possibilidade de uma reciclagem do espaço da senzala para outras funções fica aparentemente rejeitada, tendo em vista a inexistência de restos passiveis de serem associados a qualquer outro tipo de atividade. Ao que parece, este espaço, ao perder sua função, foi desativado, abandonado e arruinado.

Descartando o local de habitação dos negros, optou-se por um novo investimento nas áreas de trabalho doméstico, onde os escravos se reuniam diariamente. Os inúmeros tanques em cantaria, distribuídos pelas imediações da casa de vivenda, atendiam satisfatoriamente a esse requisito, e por essa razão foram selecionados. Entretanto, apenas no tanque situado no plano mais elevado atrás da pocilga foi recuperada uma expressiva quantidade de material do século XIX: cacos de faianças, porcelanas, vidros e cerâmicas, moedas, botões, cachimbos, projéteis, conta de colar, entre outros. Somente os cachimbos e a conta de colar, vermelha, são passíveis de serem atribuídos aos escravos.

Em seguida, considerando como possivelmente pródiga em dejetos, sobretudo dos senhores, a área entre a pocilga e a ala de serviços da casa de vivenda, designada como área da cozinha, foi aí escavada uma superfície de $46 \mathrm{~m} 2$. Este trecho foi dividido em 10 quadras de $2.00 \mathrm{~m} \times 1.50 \mathrm{~m}$, em função de especificidades do terreno, numeradas de 01 a 10; em uma sucessão que foi seguindo as necessidades ditadas pela escavação, alcançou uma profundidade média de $80 \mathrm{~cm}$. Mais quatro quadras foram posteriormente abertas, ampliadas para $2.00 \mathrm{~m} \times 2.00 \mathrm{~m}$ e numeradas de $11 \mathrm{a} 14$ (ver planta baixa da área escavada, prancha 31.

O setor 3 corresponde a uma antiga área interna de construção, conforme indicam os alicerces expostos. A escavação dos setores 2, 4 e 5 eviden- 
ciou parte das fundações de uma construção que deveria integrar, junto com a pocilga, um conjunto de prédios de apoio aos serviços. Os setores 5, 7, 10, 11, 12 e 13 expuseram uma outra canaleta, desativada, com 1. 15m de largura, que acompanha o muro da pocilga em toda a sua extensão. Sua função, à época, foi também a de captação de águas, tal como o sistema que circunda a casa de vivenda, apesar de executada em materiais e técnicas construtivas inferiores, possivelmente por se tratar de um espaço destinado a serviços.

Toda esta área escavada, de intensa circulação e grande movimento no século XIX, pela sua contiguidade com os espaços destinados ao armazenamento e processamento de alimentos, bem como à criação e matança de animais domésticos, liberou uma expressiva quantidade de material arqueológico. Considerando as precárias condições de higiene das fazendas à época, esta foi sem dúvida uma área de dejeitos, onde as coisas imprestáveis que caíam não eram removidas, apesar da sua proximidade em relação à casa. Aí foram recuperados cerca de 2500 cacos de faianças e porcelanas em diversos padrões e tonalidades, predominantemente brancos; fragmentos de grés, cerâmicas, telhas e azulejos; em torno de 2000 cacos de vidro, compreendendo gargalos, fundos e fragmentos de garrafas, vidros de remédios, copos, etc., em diferentes formatos e tonalidades; quatro pés de taças de vidro; bibelôs, bolas de gude, pregos, cravos, ferraduras, ferramentas agrícolas, argolas, correntes, fragmentos de panelas de pedra sabão e ferro, botões, adornos, ossos e dentes de animais (basicamente aves, suínos e bovinos). Passiveis de serem atribuídos aos negros, foram recuperados apenas cinco fragmentos de cachimbos de cerâmica (para a distribuição qualitativa e quantitativa deste material, ver pranchas 3 a 7l.

Dentre as louças recuperadas foi possiviel reconhecer faianças e porcelanas de diferentes procedências e padröes decorativos. As primeiras, que apresentam uma popularidade bem maior que as últimas, aparecem em branco, azul e branco e policromadas. As brancas, que podem ser simples ou com decoração em relevo, têm uma elevada freqüência em relação às demais. Todavia, tratando-se de fragmentos, fica difícil avaliar com precisão se são peças efetivamente brancas ou se correspondem a porções não decoradas de tipos bicromados ou policromados. Entre estes últimos foram identificados os seguintes padrões: "Willow" (produzido por pelo menos dois fabricantes diferentes: Petrus Regout, de Maastricht, Holanda, e Adams, Inglaterra), "Italian" Iproduzido por Copeland \& Garret, Late Spode, Staffordshire, Inglaterra, 1833 - 1847), "Flow Blue", "Geométrico", "Policromo" (produzido por Opaque de Sarraguemines, Sarre, França), "Blue or Green Edged" e "Trigo". Quanto às porcelanas recuperadas foi possivel identificar apenas as de Macau.

Ainda em faiança há objetos isolados, ligados aos cuidados com o corpo: fragmentos de um urinol e de uma bacia, em louça branca (fabricada por J. \& G. Meakin - Inglaterral, e de dois potes de produtos de beleza (um de procedência inglesa ou americana e outro, francesa).

Dentre a abundante vidraria foi possivel reconhecer garrafas de bebidas, vidros de remédios, copos, taças, bibelôs, bolas de gude, canutilhos, vidros de janela, tampas de recipientes, entre outros. Entretanto, a ausência de marcas impressas, sobretudo no caso das bebidas e dos medicamentos, diminuiu consideravelmente o potencial informativo deste tipo de material. 
Quanto às cerâmicas, foram distinguidas três categorias: a cerâmica simples, a vidrada e o grés. Incluem-se no primeiro caso as telhas, fabricadas possivelmente na própria fazenda, que apresentam impressōes geométricas, como linhas paralelas, onduladas, cruzes, etc. Aplicadas à face externa, estão sendo tentativamente interpretadas como sinais de tarefa dos escravos, que desta forma "assinavam" as telhas que moldavam em suas coxas, cada qual com a sua marca pessoal, o que facilitava o controle sobre a produção. Uma outra possibilidade é a de que sejam marcações para distinguir, em se tratando de telhas tipo canal, capas e bicas; ou ainda irregularidades com o propósito de evitar o seu deslizamento sobre o madeirame.

Também em cerâmica foram produzidos os cachimbos ou "pitos", que a iconografia da época mostra terem sido utilizadas pelos escravos, homens e mulheres indistintamente. Com fornilhos, apresentam uma decoração discreta em incisões e relevos. Esses objetos vêm sendo analisados à luz de uma hipótese, a ser testada quando as amostras recolhidas em sítios arqueológicos históricos forem suficientemente amplas para suportar um tratamento estatístico confiável: a de que tais padrões decorativos possam estar vinculados a determinados grupos africanos, enquanto privativos de tribos, clãs, etc., uma forma de manutenção da identidade étnica diante da fragmentação promovida pelo europeu. Esses padrões estão sendo comparados com os que aparecem em escarificaçōes e pinturas corporais dos negros, na iconografia da época.

Fragmentos de vasilhames cerâmicos foram resgatados, sugerindo utensilios para processamento de alimentos, confeccionados em torno mecâni$\mathrm{co}$, com ou sem vidrado. Destinadas à mesma função, foram recuperadas panelas de ferro e pedra sabão fragmentadas. Os restos dos alimentos possivelmente processados nesses recipientes resumem-se a ossos de porco e aves, de acordo com os hábitos à época, aparecendo os de gado bovino em percentual bem menos expressivo.

Quanto aos objetos metálicos, trata-se em geral de material construtivo: pregos, cravos, dobradiças, fechaduras, puxadores, etc., merecendo destaque um fragmento de instrumento de tortura de escravos, uma moeda em avançado estado de corrosão, na qual se distingue apenas a efígie de $D$. Pedro II, uma fivela, uma corrente e algumas ferraduras.

Visando detectar outras áreas de ocorrência de dejetos foram feitos novos cortes exploratórios em pontos diversos da fazenda (ver planta geral da escavação, prancha 2). Face aos resultados pouco significativos dessas sondagens, não foram feitos investimentos de natureza mais sistemática nos trechos prospectados, a exemplo do que foi possivel executar na área da cozinha, sendo considerada como pouco compensadora qualquer tentativa nesse sentido. É bem possível que o descarte de lixo de maior porte fosse feito, conforme - costume à época, junto ao curso d'água da fazenda. Contudo, a criação recente de um lago artificial em um dos prováveis locais de despejo inviabilizou a possibilidade de escavações, pelo fato da área ter sido alagada.

Todo esse material extraído das escavações corresponde à ocupação diacrônica da Fazenda São Fernando e em sua maior parte pode ser atribuído a meados do século XIX. As progressivas mudanças nos hábitos de higiene e 
conseqüentemente nas práticas de descarte determinaram novas formas de deposição e processamento do lixo, de tal modo que poucos objetos podem se: caracterizados como pertencentes a períodos mais recentes.

Do ponto de vista da investigaçáo arqueológica, em uma perspectiva mais ampla, comprometida com o entendimento dos processos que conduziram à formação social do século passado, a importância da amostra recolhida reside no excelente controle obtido, do ponto de vista documental. Os ítens recolhidos foram confrontados com o material doméstico descrito nos inventários e arrolamentos de época, com resultados bastante positivos, o que permite uma manipulação segura dos dados levantados.

O interesse desta amostra é de natureza fundamentalmente comparativa e, enquanto produzida por um segmento afluente e dominante, apresenta um perfil que deverá ser sobreposto ao de contextos semelhantes em outros sítios, ou contraposto em relação aos dessemelhantes, de tal forma que permitia a constałação de regularidades e a configuração de padrões comportamentais próprios a cada uma das categorias sociais examinadas. Quanto à notável ausência de vestígios do cotidiano da classe subalterna, por seu lado, tão informativa quanto a sua presença, deverá ser reexaminada em outros contextos análogos, à luz desta mesma proposição.

A restituição material de um passado: um ensaio museográfico

Com o objetivo de preservar, no âmbito da própria fazenda, os objetos recuperados nas escavações arqueológicas e atendendo à preocupação de restituir à população, através de um processo museológico, a informação e o conhecimento daí extraídos, foi selecionada uma área destinada a abrigar os vestígios materiais daqueles que ergueram e transformaram a Fazenda São Fernando em uma das principais unidades cafeicultoras do Vale do Paraiba: os senhores e seus escravos.

Considerando o braço negro como o mais sólido alicerce deste empreendimento, a escolha recaiu sobre o espaço que se supõe ter sido utilizado como uma das formas extremas de domínio e coerção sobre esses indivíduos: um cárcere existente nas dependências da fazenda. Para tanto, foi elaborada uma proposta para subsidiar e orientar a concepção de uma exposição que ao mesmo tempo transmita os resultados da pesquisa e apresente as evidências materiais encontradas.

As exposições têm representado um importante papel na divulgação científica, especialmente das áreas relacionadas ao estudo da cultura material, e têm ocupado um lugar destacado entre as inúmeras responsabilidades dos museus. Ao lado da aquisição, conservação, documentação, a exposição trouxe à museologia a realidade do público, que vai à sua procura com necessidades e expectativas. 
A historiografia sobre os museus assinala mudanças significativas nas exposições. De espaços para apresentação de objetos, transformaram-se gradualmente em suportes de um processo de comunicação. A possibilidade de serem concebidas, viabilizadas e analisadas como discursos que ligam os atores sociais nas operações de produção, transmissão e recepção das mensagens, dá às exposições novos desafios (Schiele, B. \& Boucher, L., 1988).

O local escolhido como cenário da musealização (fotos 2 e 3), a prisão dos escravos, constituiu-se como a base desse processo de comunicação, qualificando-se por suas próprias características e orientando o discurso museográfico. Ao mesmo tempo, tornou-se fundamental para que o visitante possa sentir a atmosfera de opressão, isolamento e tortura, inerentes ao cotidiano dos negros durante o regime escravista.

Tendo em vista o fato de que a Fazenda São Fernando está em vias de ser transformada em uma fundação, e nesta condição estará aberta ao público, a elaboração da prosposta levou em consideração a necessidade de se transmitir à comunidade a sua trajetória histórica, apresentar os vestígios do seu dia-a-dia no século XIX e resgatar este espaço marcado pelo terror do período escravocrata.

Apoiando-se nos vestígios recuperados, pertencentes aos dois segmentos polares que conviveram na unidade produtiva, a exposição pretende expor a dualidade e os conflitos que caracterizaram essa formação social, inúmeras vezes exposta pela historiografia e explicitada no material resgatado: por um lado, faianças, porcelanas, produtos de toucador: por outro, a sofrida vivência dos escravos trazida à luz pelos objetos de trabalho e tortura. Mais ainda, pretende estimular uma reflexão sobre o processo sócio-econômico que determinou o florescimento e a derrocada da cafeicultura no Vale do Paraíba fluminense.

Esta proposta conceitual foi apresentada em duas partes;

- O Cotidiano dos Senhores

- O Cotidiano dos Escravos

A primeira parte compreende a exposição de malerial em duas vitrinas: "Cuidados com higiene e vestuário: o requinte dos senhores" e "O processamento dos alimentos: o gosto dos senhores". A segunda parte, condensada em uma única vitrina, disposta espacialmente em oposição à primeira, em evidente contraponto, trata de "Costumes, trabalho e suplício: a trajetória dos escravos". A distribuição e o conteúdo das vitrinas denuncia, pela própria natureza dos objetos exibidos, o forte dualismo da sociedade rural escravocrata do século passado, bem como o regime de tirania, violência, e autoritarismo que a sustentou.

O cárcere é um cômodo alongado e estreito $(2.40 \mathrm{~m}$ de largura na entrada e $2 \mathrm{~m}$ no fundo $\times 9 \mathrm{~m}$ de comprimento), sem janelas, com as paredes revestidas de pedra. Apenas um pequeno postigo gradeado na parede do fundo $(60 \mathrm{~cm} \times 80 \mathrm{~cm})$, a $1.50 \mathrm{~m}$ de altura do chão, permite a entrada de um pouco de luz e ar, criando uma atmosfera sombria e pesada. Os barrotes do piso do andar superior são aparentes, dispostos no sentido da largura do cômodo. 
Neste ambiente, a diagramação do discurso museográfico procurou apresentar a idéia da exposição a partir dos seguintes suportes

Painéis - para elucidação do conceito

Vitrinas - para apresentação dos vestígios arqueológicos que justificam o encaminhamento temático (prancha 9).

Folheto - narração sobre a história da Fazenda São Fernando.

Vídeo - apresentação visual de um histórico sobre a ocupação do Vale do Paraiba e o ciclo do café.

Armário - armazenamento das coleções e documentação sobre a pesquisa. a saber:

A planta baixa (prancha 8) explicita o encaminhamento da proposta,

Painel 1 - apresentação do tema da exposição.

Painel 2 - título: "Cuidados com higiene e vestuário: o requinte dos senhores". Texto: explicando aspectos do cotidiano da classe dominante naquela região, no século XIX.

Vitrina 1 - apresentação dos fragmentos recuperados na pesquisa (prancha 9A): - vidros de remédio (a) - potes de creme (b) - bacia (c) - urinol (d) - botões (e) fivelas $(f)$ - objetos comparativos: urinol, vidros de farmácia. - linguagem de apoio: -etiquetas nominativas -reprodução de gravura -reprodução do texto de um inventário de época

Painel 3 - título: "O processamento dos alimentos: o gosto dos senhores" Texto: apresentação dos hábitos alimentares e dos usos e costumes à mesa, no século XIX.

Vitrina 2 - apresentação dos fragmentos recuperados na pesquisa (prancha 9B). - ossos (a) - panelas (b) - louças (c) - garrafas (d) - copos (e) - objetos comparativos: panela, prato, garrafa e copo. - linguagem de apoio: - etiquetas nominativas - reprodução de gravura

Painel 4 - título: "Costumes, trabalho e suplício: a trajetória dos escravos". Texto: apresentação de aspectos relevantes sobre o regime de trabalho dos escravos.

Vitrina 3 - apresentação dos fragmentos recuperados na pesquisa (prancha 9C). - cachimbos (a) - ferro de engomar (b) - correntes (c) - instrumentos de tortura (d) objeto comparativo: cachimbo - linguagem de apoio: - etiquetas nominativas reprodução de gravuras - reprodução de texto sobre o regime de trabalho dos escravos.

Armário - Um armário em ferro e vidro está destinado a armazenar o material arqueológico que não estará exposto nas vitrinas. Disposto em gavetas, devidamente identificado, este material poderá também ser conhecido pelo público. Em uma gaveta central deverá ficar um álbum como fotos das escavações arqueológicas.

Ainda como linguagem de apoio, este projeto conta com um folheto (texto e fotos) que apresenta um resumo da história da fazenda, e com projeções de vídeos, destinados a transmitir um histórico da ocupação da região, da empresa cafeicultora que nela se estabeleceu e da São Fernando enquanto uma unidade produtiva aí inserida. 
Considerações finais

A Arqueologia, ciente da sua responsabilidade social e disposta a dar a sua contribuição para a preservação de uma memória comunal no Vale do Paraíba, aliou-se à Museologia em um programa que prevê a implantação de pequenos museus de sítios em algumas das antigas unidades cafeicultoras da região.

Enfatizando, em cada um, diferentes aspectos da história do Vale, pretende entregar à comunidade e aos inúmeros visitantes que para lá se dirigem com fins turísticos, atraídos pela arquitetura das fazendas e pela opulência dos seus interiores, o roteiro de um conjunto integrado de exposições que thes permita transcender essa mera fruição estética. Apresentando materialmente os elementos remanescentes das forças que atuaram na construção e no desmantelamento de uma das empresas mais lucrativas do Império, deseja estimular reflexões sobre um processo histórico de capital importância para os rumos da nação brasileira e sobre a ideologia que o sustentou.

Procurando não distorcer esse passado através de uma classificação e exposição seletiva dos elementos recuperados, propõe uma apresentação ao público da totalidade do acervo retirado do terreno. Evitando a sua remoção para as gavetas das instituições de pesquisa, assegura a sua permanência no contexto em que foi produzido e/ou utilizado, consumido e descartado, garantindo desta forma a preservação do seu significado e da sua identidade.

Parte integrante e indissociável desse meio, esse patrimônio é assim devolvido e reintegrado, enquanto passado, à realidade presente, evitando o corle de uma perspectiva e mantendo um sentido de continuidade, ao mesmo tempo em que expõe a descontinuidade, as mudanças, as contradições e os conflitos inerentes ao processo. A cumplicidade na adoção dessa política vem unindo, nesta pesquisa, as duas disciplinas, tornando o espaço museográfico o seu ponto de convergência e conexão com o presente, ao atuar na mediação entre o passado e a atualidade.

\section{REFERÊNCIAS}

Fontes Manuscritas

Arquivo Nacional

Sesmarias. Rio Paraíba. Serra do Mar. Sertão da Paraíba.

Sesmarias. Paraíba - Rio. Medição.

Arquivo Casa Paroquial Vassouras

Livros de Casamentos de Pessoas Livres.

Livros de óbitos de Pessoas Livres.

Arquivo Cartorário Vassouras

Demarcações- Emancipações- Execuções de Sentenças- Executivos

Hipotecários- Inventários- Homicídios-Testamentos 
Cartório $1^{\circ}$ Ofício Vassouras

Inventários

Cartório $2^{\circ}$ Ofício Vassouras

Inventários- Livros de Transcrição de Transmissões- Livros de Escrituras

Cartório 3 o Ofício Vassouras

Livros de Transcrição de Transmissões

Cartório $4^{\circ}$ Ofício Vassouras

Livros de Registro de Imóveis

Fontes Impressas

Jornais: O Vassourense, 1882-1891

BIBLIOGRAFIA

ALBUQUERQUE, Manuel Maurício de. Pequena história da formação social 1981 brasileira. 2a ed., Rio de Janeiro, Graal.

ANDRADE LIMA, Tania; FONSECA, Marta P. R.; SAMPAIO, Ana Cristina O.; 1989 FENZL-NEPOMUCENO, Andrea; MARTINS, Antonio Henrique D. A tralha doméstica em meados do século XIX: reflexos da emergência da pequena burguesia do Rio de Janeiro. Dédalo, Publ. Av. 1:205-30.

CANABRAVA, Alice P. A grande lavoura. In Sergio Buarque de Hollanda (dir.), 1974 História Geral da Civilização Brasileira.II (4): 85-137.

COSTA, Emília Viotti da. O escravo na grande lavoura. In Sergio Buarque de 1976 Hollanda (dir.). História Geral da civilizaçâao Brasileira, 3a ed. rev., São Paulo/Rio de Janeiro, DIFEL, II (3): 135-188.

COSTA, Emília Viotti da. Introdução ao estudo da emancipação política do 1977 Brasil. In: Carlos Guilherme Mota (org.). Brasil em perspectiva. 8a ed., Rio de Janeiro, DIFEL, pp 64-125.

COSTA, Emília Viotti da. Da Monarquia à República: momentos decisivos. 4a 1987 ed., Brasiliense, São Paulo.

FALCÓN, Francisco C. \& Ilmar Rohloff de Mattos. O processo de independên1972 cia no Rio de Janeiro. In Carlos Guilherme Motta (org.), 1822: Dimensões. São Paulo, Perspectiva, pp 292-339.

FRANCO, Maria Sylvia C. Homens Livres na Ordem Escravocrata. Ensaios 3, 1974 Ática, São Paulo. 
FURTADO, Celso. Formação Econômica do Brasil. 14a ed., São Paulo, Cia. 1976 Editora Nacional.

MUNIZ, Célia Maria Loureiro. Os donos da terra. Um estudo sobre a estrutura 1979 fundiária do Vale do Paraíba fluminense, no século XIX. Dissertação de Mestrado apresentada à Universidade Federal Fluminense. ms.

PINTO, Virgilio Noya. Balanço das transformações econômicas no século XIX. 1977 In: Carlos Guilherme Mota (org.). Brasil em perspectiva. 8a ed., Rio de Janeiro, DIFEL, pp 126-145.

SCHIELE, B. \& L. Boucher. Exposition Scientifique: Essai sur la definition du 1988 genre. La Divulgation du Savoir - Théorie et Pratiques. ExpoMedia, 16(3), Paris.

SODRÉ, Nelson Werneck. Formação Histórica do Brasil. 9a ed., Rio de Janeiro, 1976 Civilização Brasileira.

STEIN, Stanley. Grandeza e decadência do café no Vale do Paraíba. São Paulo, 1961 Brasiliense. 


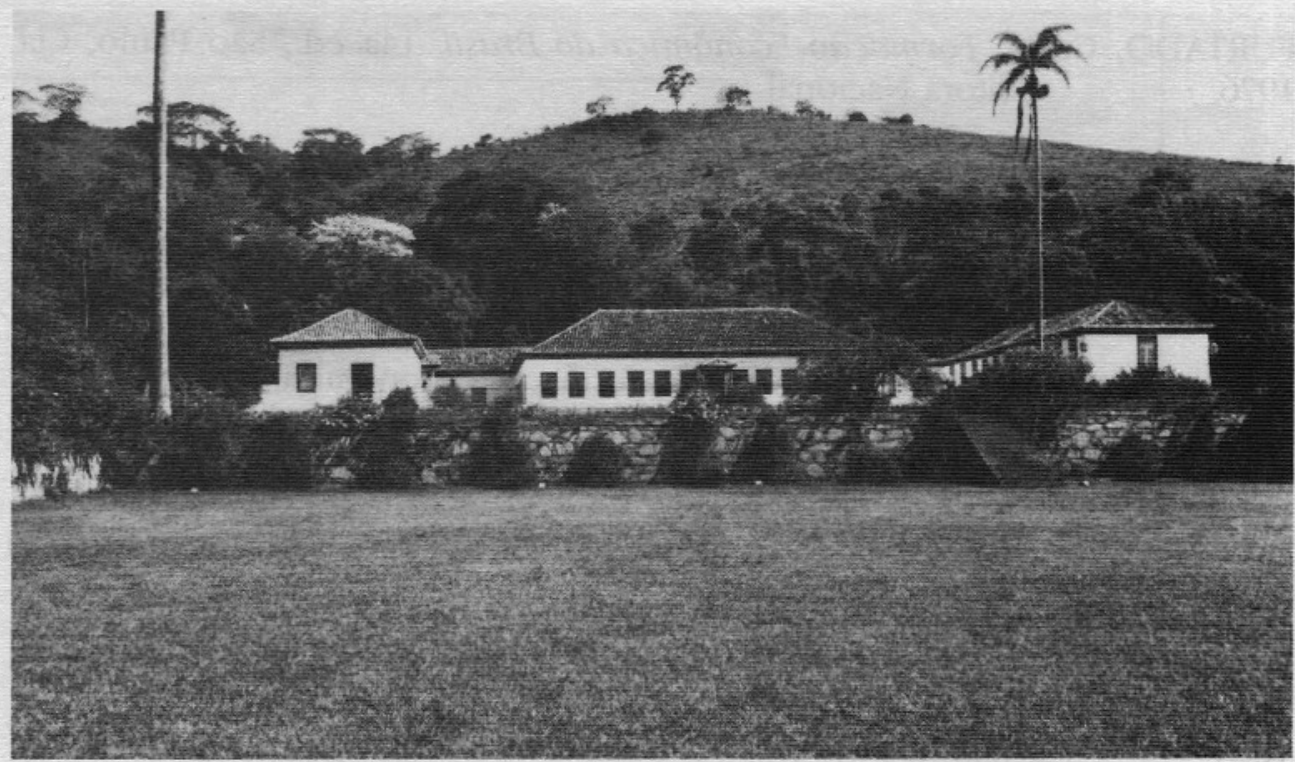

Foto 1: O conjunto arquitetônico da Fazenda São Fernando. À sua frente, o antigo terreiro de café.

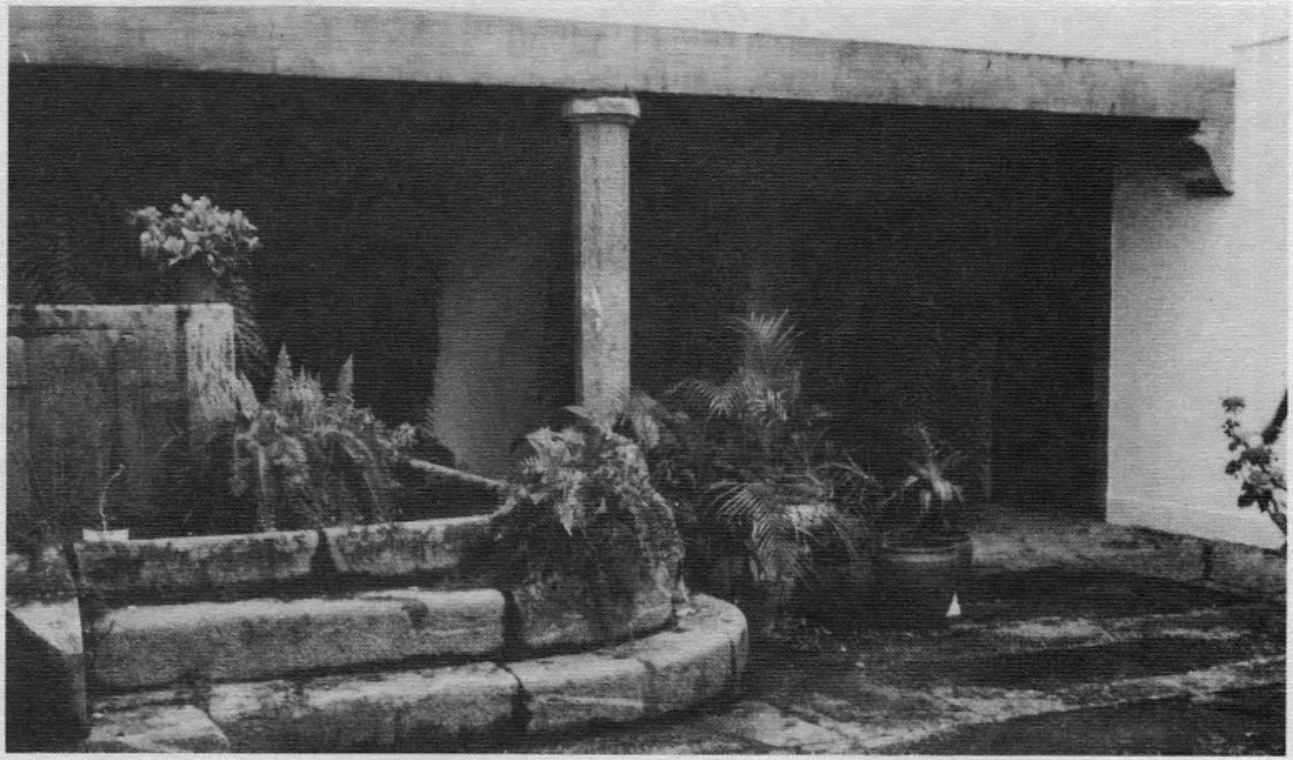

Foto 2: O pátio interno com o tanque de lavagem do café à esquerda. A seta à direita indica a porta de acesso ao antigo cárcere. 


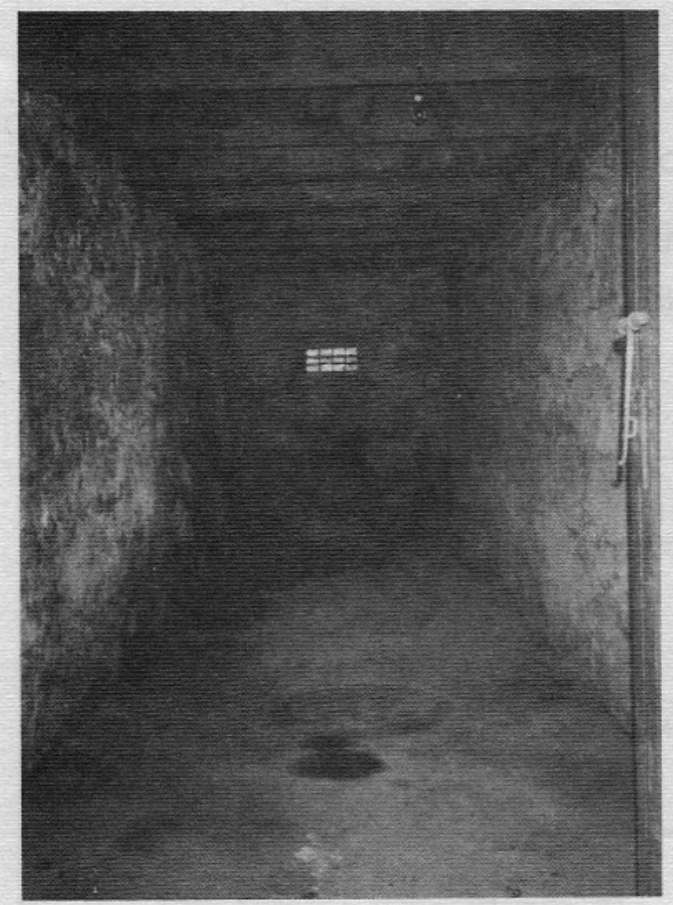

Foto 3: O antigo cárcere dos escravos da Fazenda São Fernando, a ser transformado em Museu.

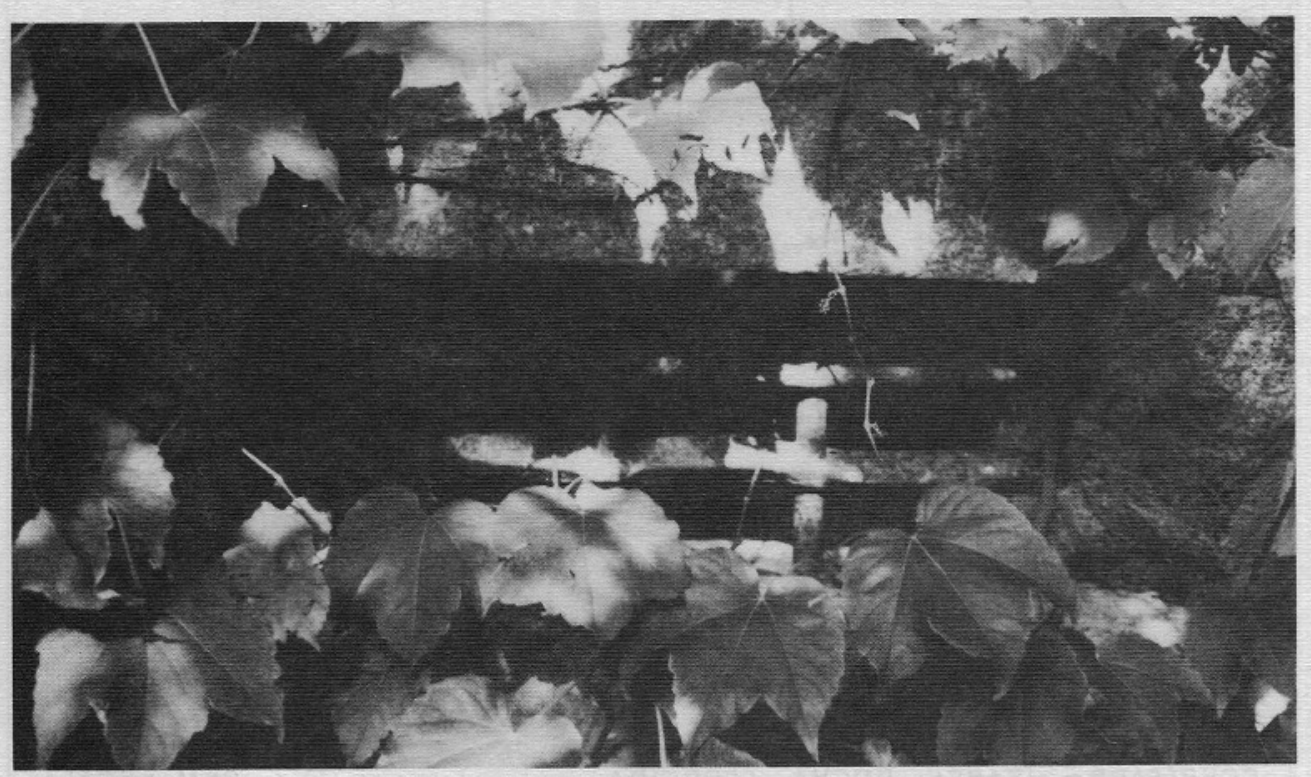

Foto 4: O pequeno postigo gradeado, única abertura para entrada de luz e ar no cárcere. 


\section{FAZENDA SÃO FERNANDO}

QUADRILÁTERO

RECONSTITUIĊÃO HIPOTETICA
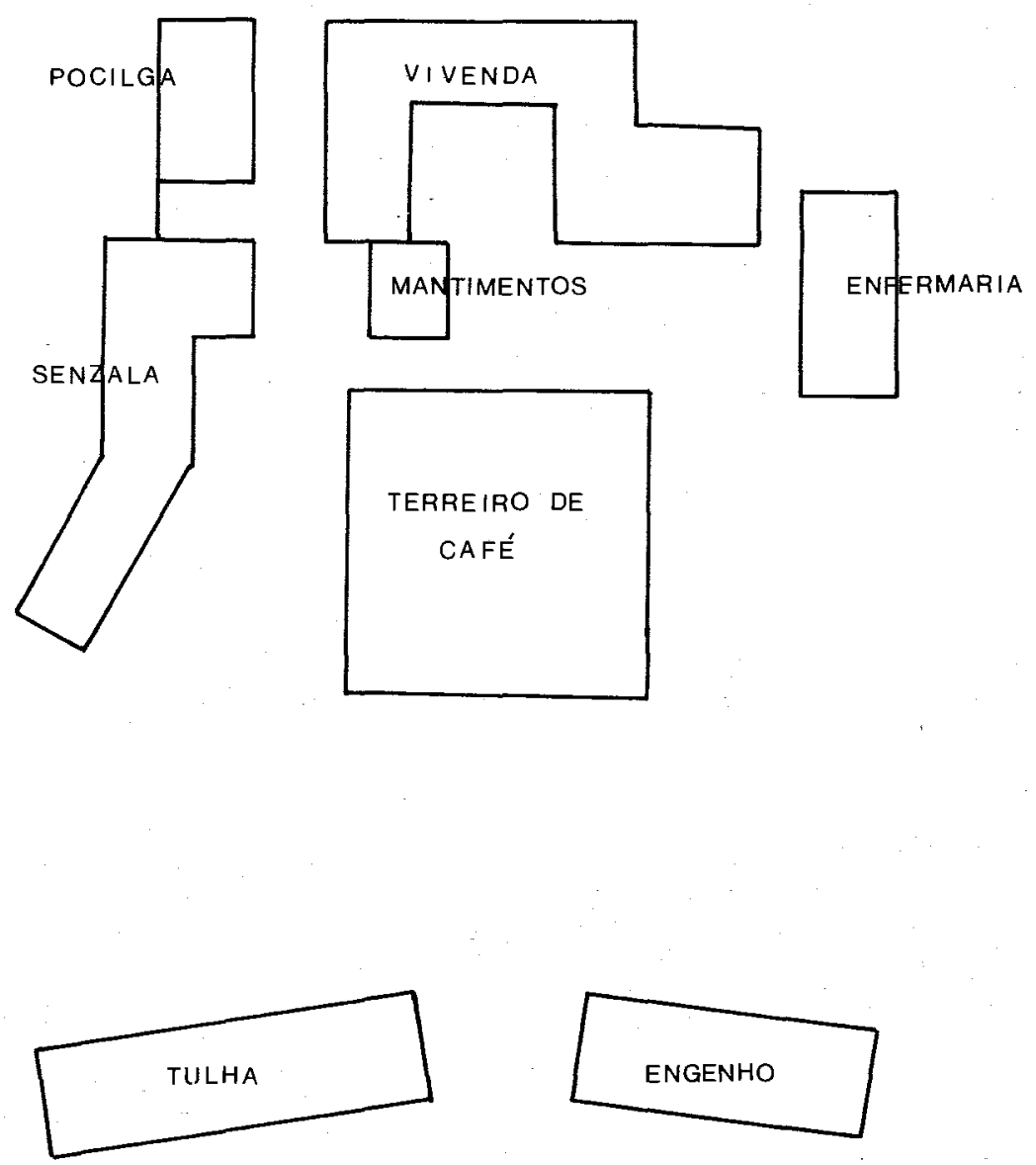

CCEP/FABP - ISABEL ROCHA FERREIRA

SEM ESCALA 


\section{FAZENDA SÃO FERNANDO}

MASSAMBARÁ - VASSOURAS - RIO DE JANEIRO

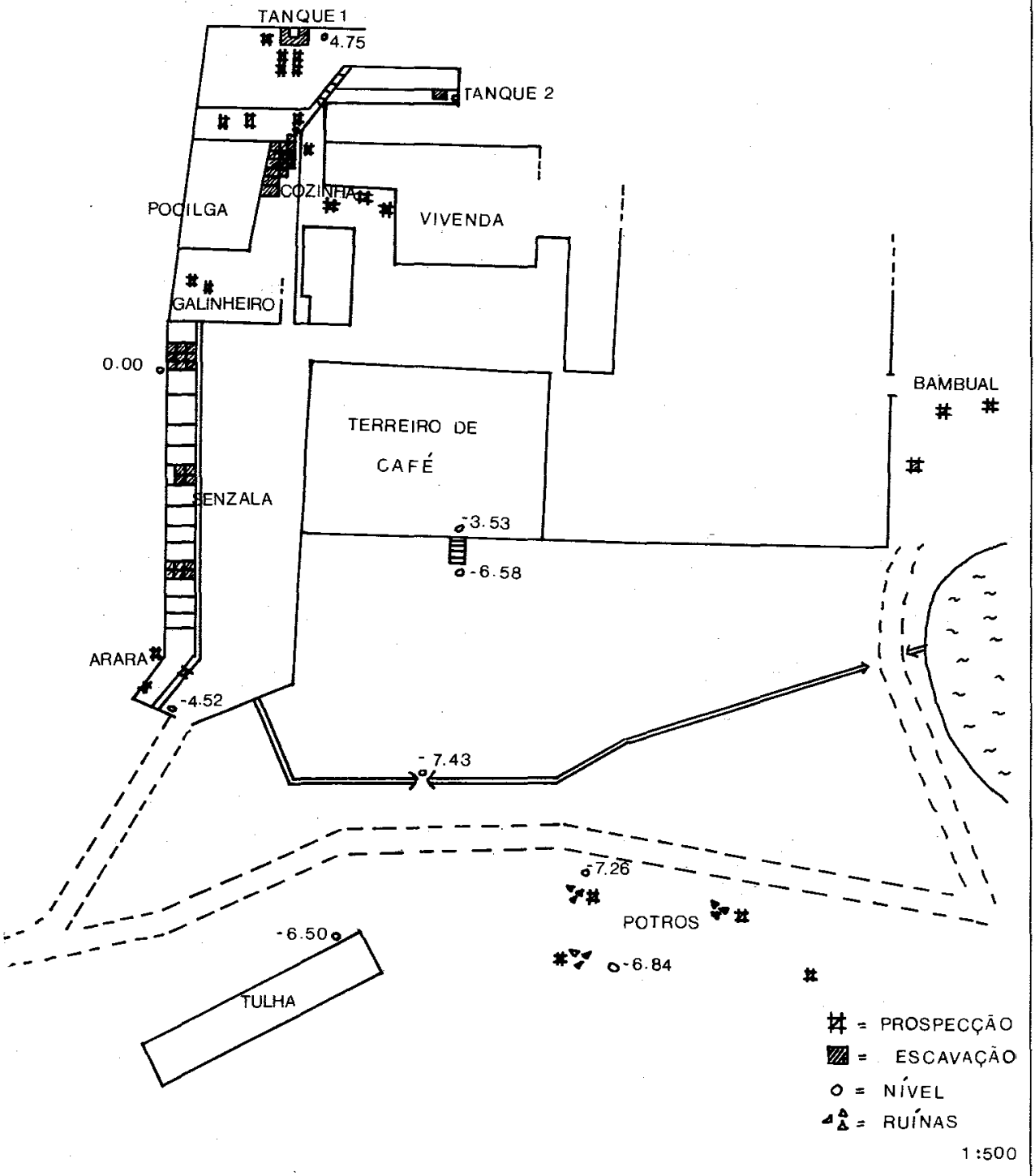

Prancha 2 


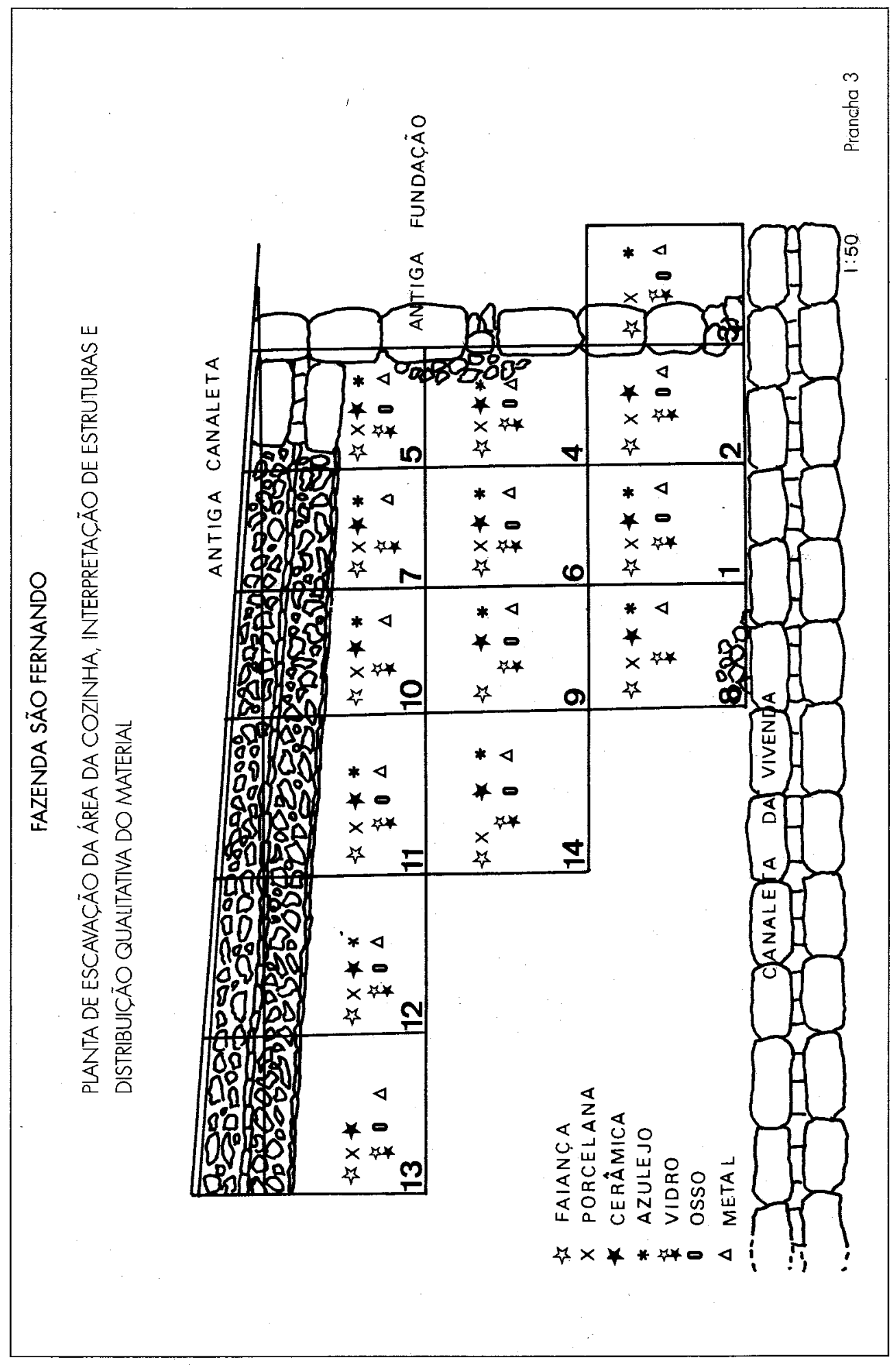




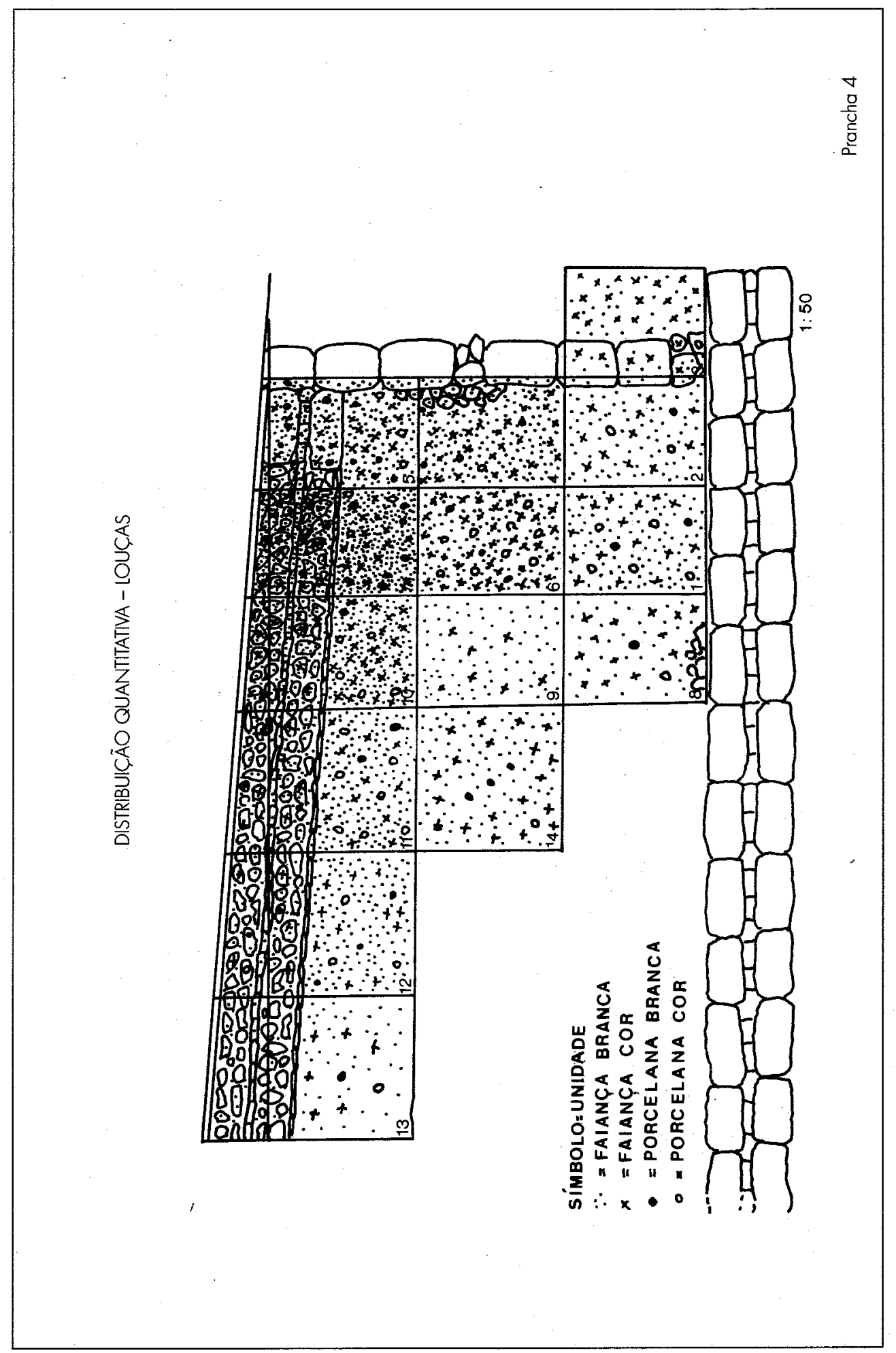




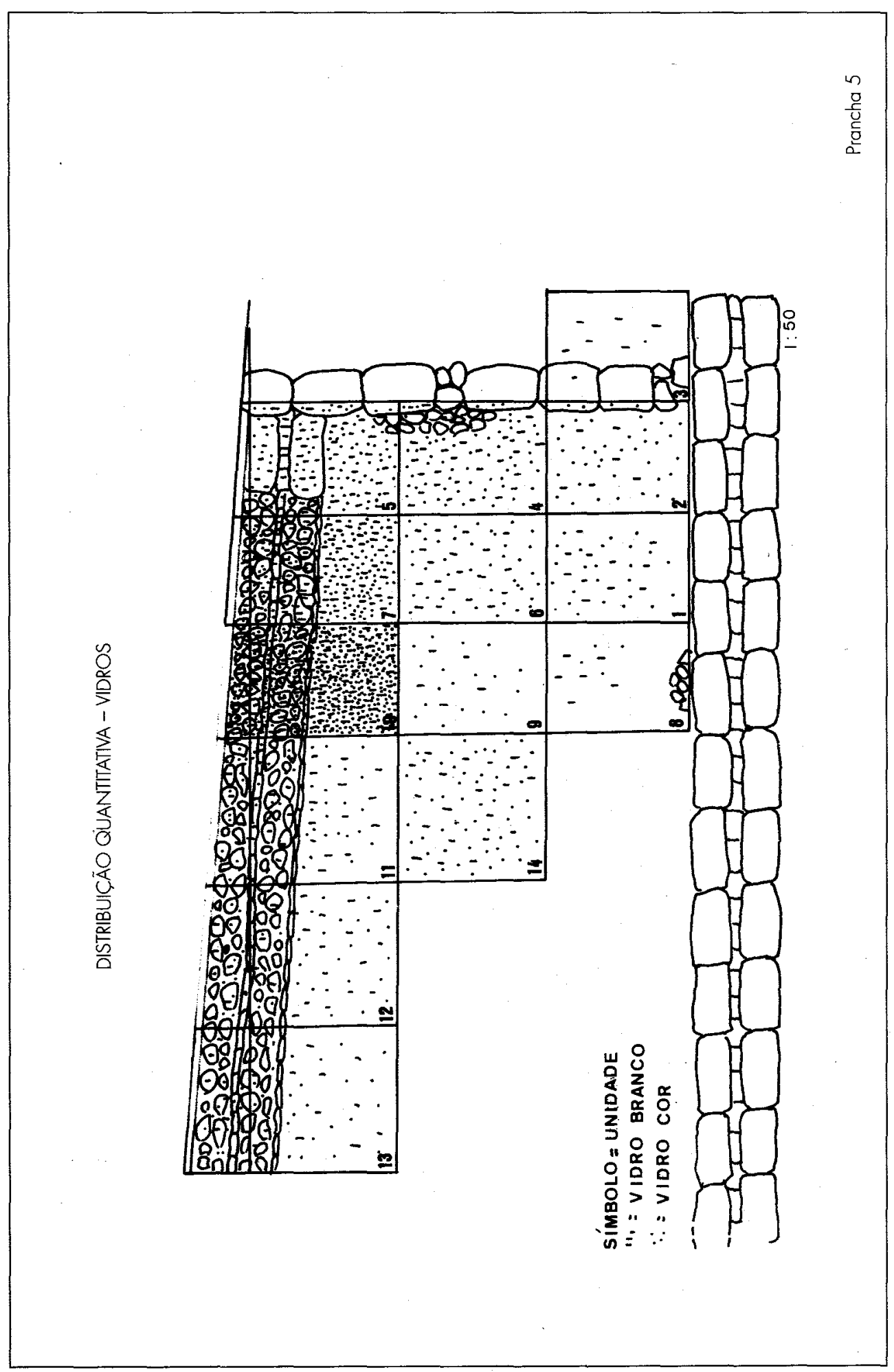




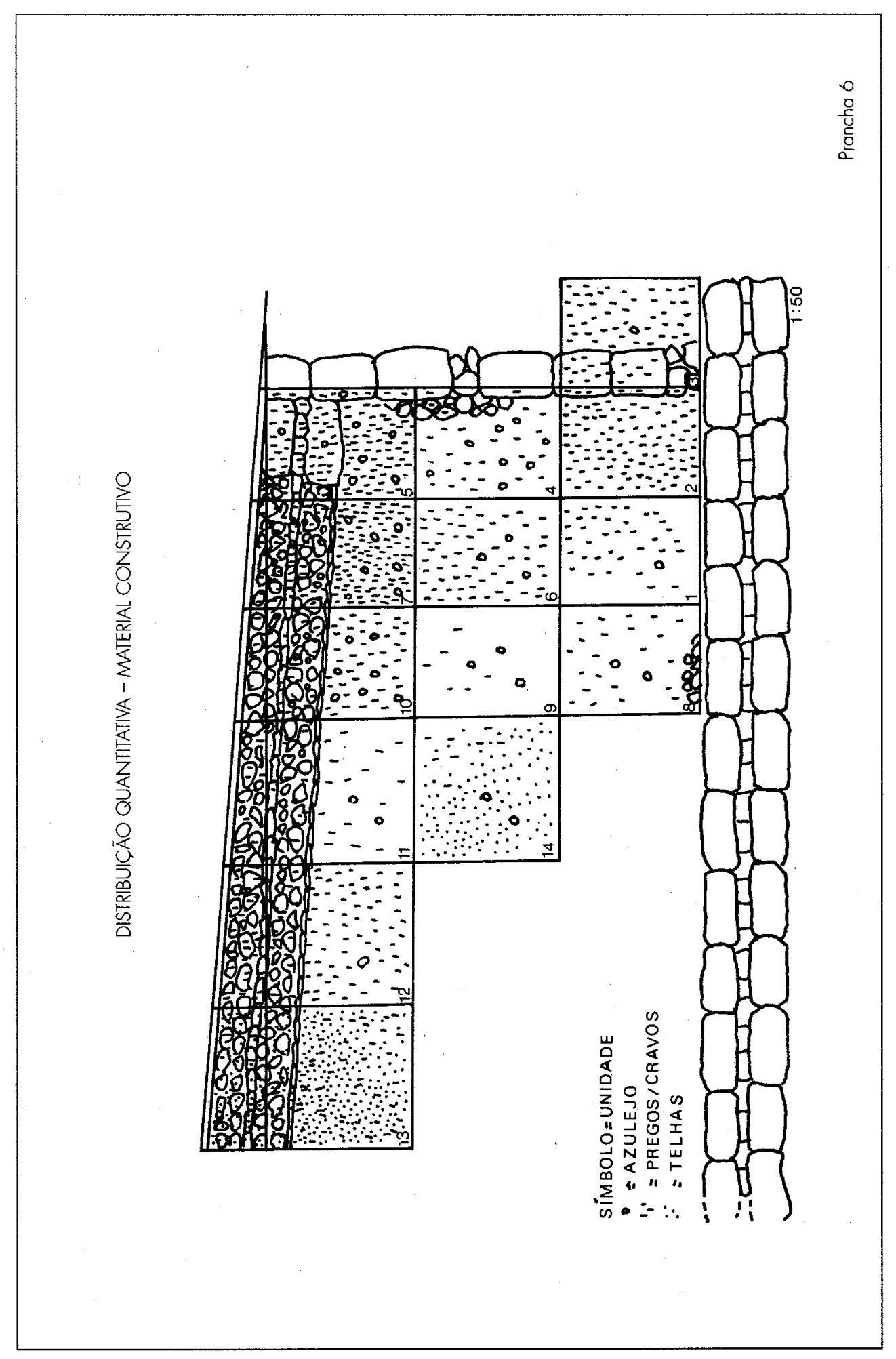




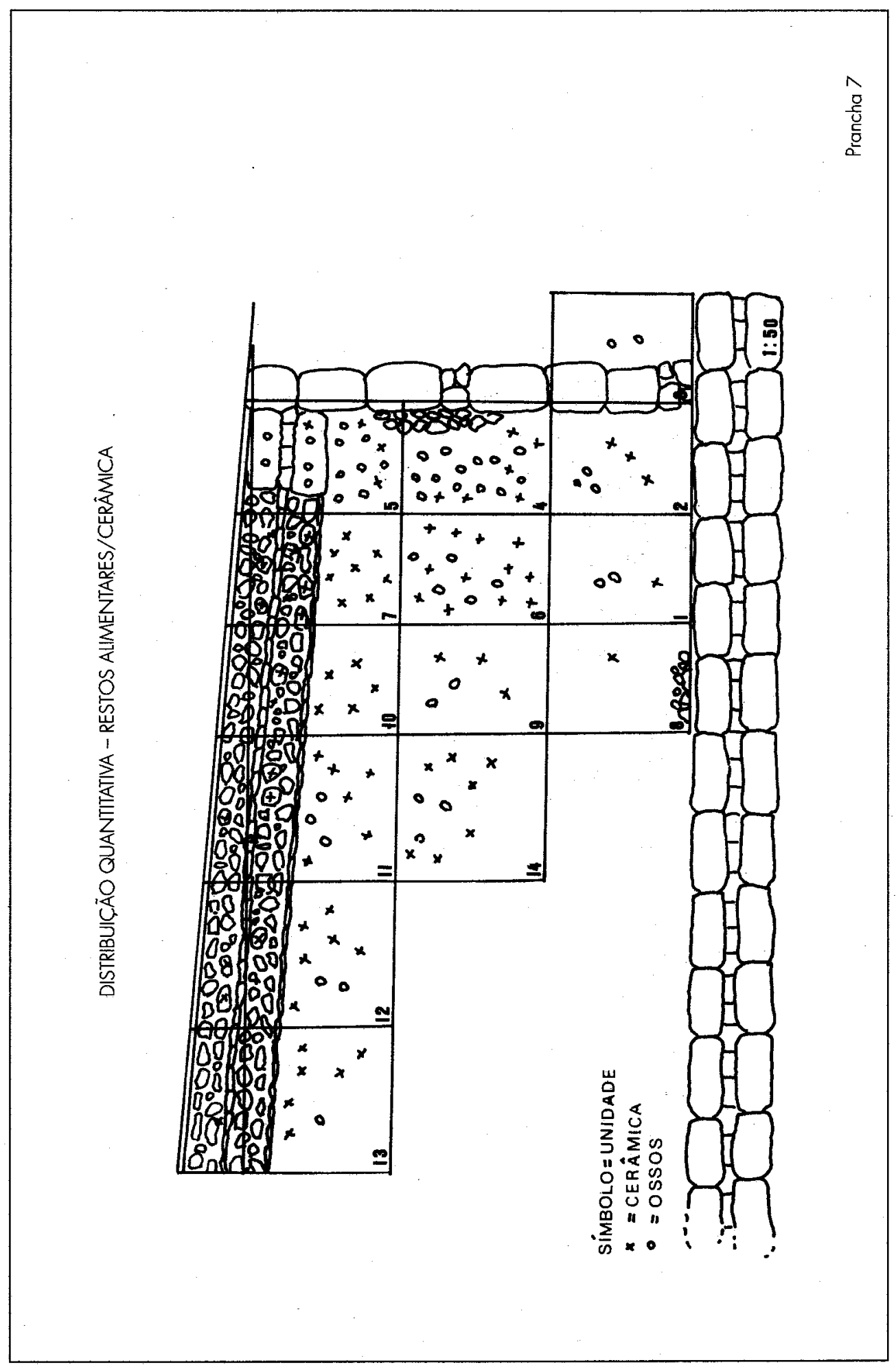




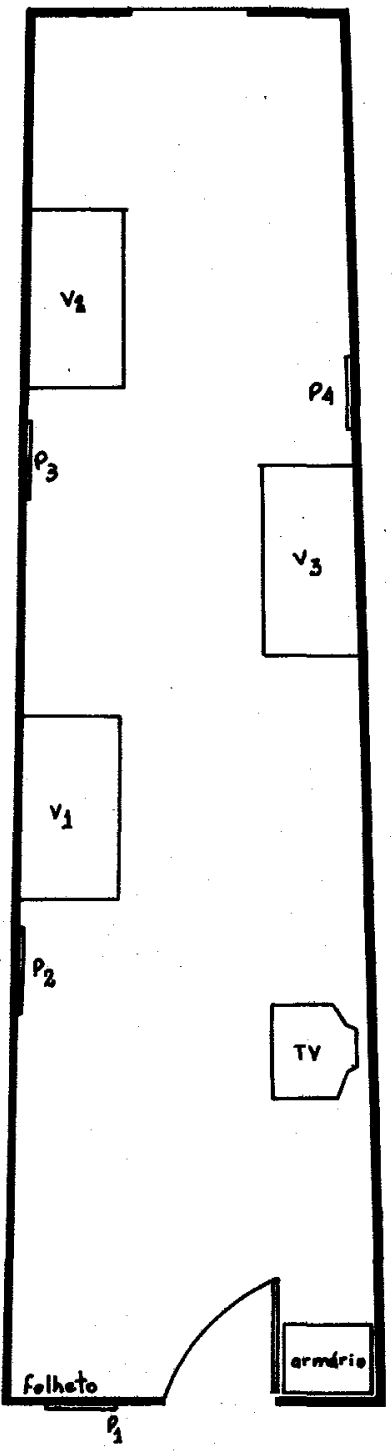

Planta Baixa esc. 1:50 of 20 so $100 \mathrm{~cm}$ des.: Lourenço, Déía
Neliana Tojar 


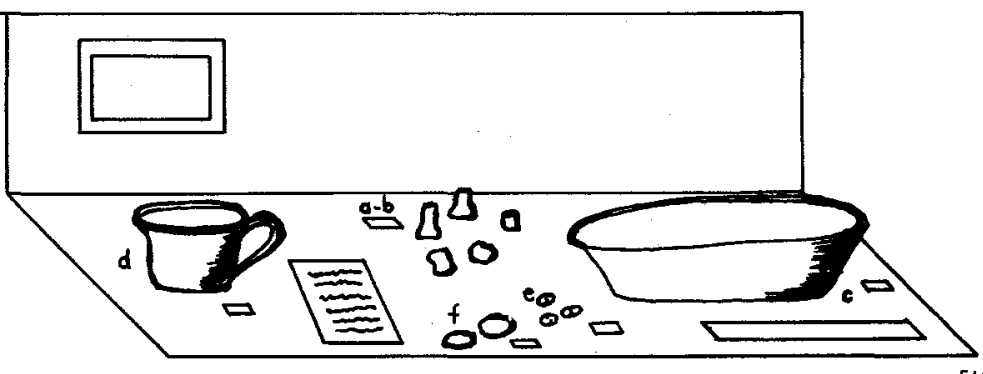

FIG.A
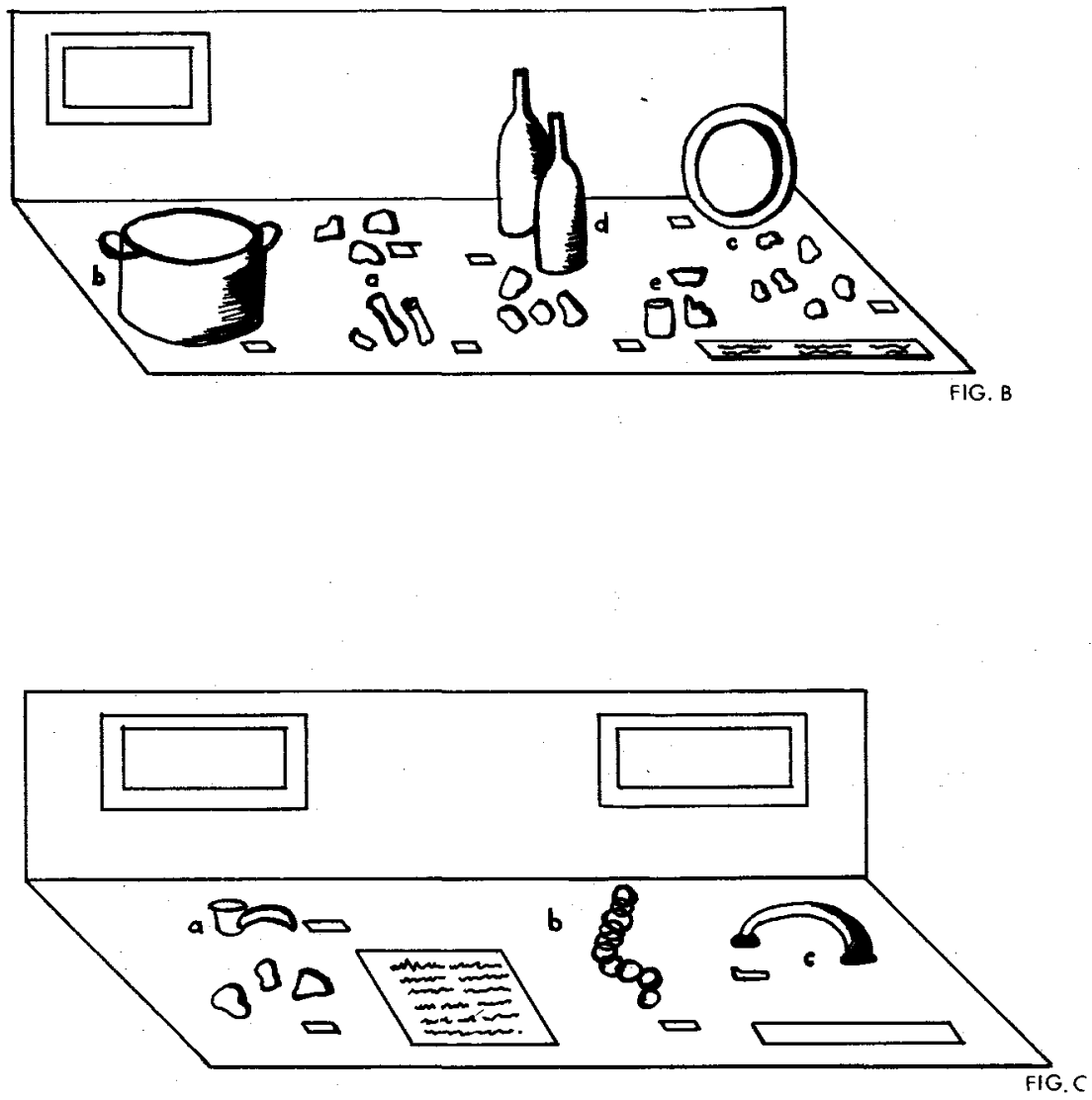

Prancha 9 
Eclecticism in Brazilian architecture: a scenery for modernization.

Annateresa Fabris

The author enhances the social and cultural meaning of Eclecticism, beyond the domain of Architecture and the level of stylistic phenomena. This frame of reference allows her to understand in a historical key its scenographical tendencies and the taste for magnificence, expressiveness and monumentality, as well as its links with the past. Some specific features of Brazilian Eclecticism are then described, as its anti-colonialistic bias. Neoclassical movement is included as a late manifestation of Eclecticism which survives until the establishment of a new kind of relationship with modernity - mediated by technology.

UNITERMS: Eclecticism. Eclecticism and architecture (Brazil). Eclecticism, modernity, modernization.

An. MP, NS 1: pg. 131, 1993.

São Paulo antigo, uma encomenda da modernidade : as fotografias de Militão nas pinturas do Museu Paulista.

Solange Ferraz de Lima e Vânia Carneiro de Carvalho

Por ocasião das comemorações do centenário da Independência do Brasil em 1922, o então diretor do Museu Paulista, Affonso de Escragnole Taunay, empenhousse na montagem de exposiç̃os voltadas para a reconstituição arcaizante do passado urbano de São Paulo. Parte desse projeto consistiv em encomendas de pinturas realizadas a partir de matrizes fotográficas do século passado. O presente estudo discute as estratégias visuais presentes na transcodificaçăo de objetos iconográficos de natureza diversa no ámbito do espaço celebrativo do Museu e seus desdobramentos ideológicos, implícitos nas ações de caráter nacionalista, 'educacional e preservacionista.

UNITERMOS: Iconologia. Pintura e modelos fotográficos. História do imaginário (São Paulo "Colonial"). História de coleçôes (Museu Paulista, décáda de 20).

An. MP. NS 1; pg. 147, 1993.

Ancient São Paulo, modernity's commission: Militão's photographs as models for oil paintings at the Museu Paulista.

Solange Ferraz de Lima e Vânia Carneiro de Carvalho

The centennial commemoration of Brazil's Independence in 1922 offered the director of the Museu Paulista at that time, Affonso de Escragnole Taunay, the opportunity to organize public exhibitions dedicated to an archaizing recreation of São Paulo's urban past. Part of this commemoration resulted in commissioning well known artists to produce oil canvasses from 19th. - century photographic sources. The present study examines the visual strategies in the translation of dissimilar iconographic media, considered within the Museum's celebrative functions, and the ideological implications in their nationalistic, pedagogic and conservational aims.

UNITERMS: Iconology. Painting and photographic models. History of the imaginaire ("Colonial" São Paulo). History of collections (Museu Paulista, 1920's)

An. MP. NS 1: pg. 147, 1993.

Sintomas do modo de vida burguês no vale do Paraiba, séc. XIX. Fazenda São Fernando, Vassouras RJ (Exploraçăo arqueológica e museológica).

Tânia Andrade Lima, Maria Cristina Oliveira Bruno e Marta Ferreira Reis da Fonseca

No âmbito de um projeto voltado para investigar arqueologicamente o surgimento do modo de vida burguês, que antecede a instalação da burquesia propriamente dita no país, vêm sendo pesquisadas unidades de produção de café implantadas em meados do século passado no Vale do Parába Fluminense. A Fazenda São Fernando, situada no município de Vassouras RJ, na condição de um dos mais notáveis exemplos do processo de expansão, apogeu e decadência desta monocultura na região, foi trabalhada com vistas a se tornar um dos espaços destinados ao conhecimento e divulgação desse passado. A Arqueologia e a 
Museologia, operando em fina sintonia, estão expondo e restituindo à comunidade as informações recuperadas em escavações sistemáticas na área e desta forma garantindo a preservação da sua memória.

UNITERMOS: Arqueologia Histórica. Exposição museológica. Fazendas de café, Vale do Paraíba, RJ., séc. XIX. Modo de vida burguês.

An. MP. NS 1: pg. 179, 1993.

Symptoms of a bourgeois way of life, 19th-- century Paraiba Valley: Fazenda São Fernando, Vassouras RJ (An archaeological and museological exploration).

Tânia Andrade Lima, Maria Cristina Oliveira Bruno e Marta Ferreira Reis da Fonseca In the scope of an archaeological project that deals with the arising of a bourgeois way of life, which came before the establishment of the bourgeoisie itself, coffee plantations from middle 19th century in the Vale do Paraiba are being investigated. The Fazenda São Fernando, located in Massambará, county of Vassouras, RJ, as one of the most conspicuous examples of the rise and fall process of the monoculture in the valley, has been worked out to become one of the places to disclose such past. Archaeology and Museology, acting in concert, are displaying and returning to the community all data recovered through sistematic diggings, thus assuring the preservation of the valley's memory.

UNITERMS: Historical Archaeology. Museological exhibit. Coffee plantations, 19th.- century Paraíba Valley, RJ. Bourgeois way of life.

An. MP, NS 1: pg. 179, 1993

A problemática da identidade cultural nos museus: de objetivo (dẻ ação) a objeło (de conhecimentol.

Ulpiano T. Bezerra de Meneses

Os museus são comumente tidos como poderosos meios de definir e reforçar identidades. $\bigcirc$ autor propõe que ao invés de tais fins ideológicos, eles considerem a identidade como objeto de análise crítica e compreensão histórica. Aponta vários traços problemáticos da identidade, sobretudo na sua estrutura de processo sócio-cultural e nas suas funçōes contrastivas. A seguir, examina criticamente respostas usuais dos museus a reivindicações de identidade lem especial as que pressupõem a superioridade do conhecimento interior ou étnico sobre o acadêmico). Postula-se a necessidade da abordagem crítica, sempre, como única forma de afrontar o tema da alteridade, independentemente das lutas pelo monopólio da verdade. Traça-se, por fim um paralelo entre a mostra museológica e o conceito de "texto discursivo", formulado pela História e pela Antropologia: as exposições não devem ser nem uma representação absoluta, nem uma expressão subjetiva; mas uma construção dialéfica, contigente e contestável - capaz de fertilizar.

UNITERMOS: Identidade (processo sócio-cultural). Museologia. Museus: funções ideológicas versus críticas. An.MP, NS 1: pg. 207, 1993.

Museums and the problematic concept of cultural identity: from objective (of action) to object lof knowledgel.

Ulpiano T. Bezerra de Meneses

Museums are usually seen as valuable means to attain and reinforce cultural identities. The author argues that, instead of such ideological goals, they should consider identity as an object of critical analysis and historical understanding. Several problematic features are pointed out, mainly identily's nature as a socio-cultural process and its contrastive functions. Current answers of museums to identity claims are then critically analyzed lparticularly the alleged preeminence of inner or ethnic knowledge over 